\title{
Evaluation of Clean Water Distribution Development in Bee Timor-Leste, E.P Post Administrative Dom Aleixo Dili Municipality
}

\author{
Zeferino Soares Lopes, Sri Sumiyati , M Arief Budihardjo \\ Master of Environmental Engineering Study Program, Diponegoro University \\ Department of Environmental Engineering, Diponegoro University \\ zeferinosoareslopes@gmail.com, srisumiyati@lecturer.undip.ic.id, ariefbudihardjo@lecturer.undip.ac.id
}

\begin{abstract}
Post Administrative Dom Aleixo is a part of Dili City with an area of $33.12 \mathrm{~km} 2$, the population in 2015 was 130,095 people. The purpose of this study was to determine the discharge capacity of the springs which is still sufficient to distribute water for the next 10 years. The method used is geometric and Epanet 2.2. The simulation results of Epanet 2.2 for the development of a clean water distribution network system are known to have 46 nodes that have residual pressure below the BTL, E.P standard. It takes repairs for $30 \%$ of the pipes because the pipe diameters are no longer able to drain water according to the standard hydraulic criteria. Repair efforts are to replace the pipe diameter to reduce water loss by $20 \%$ and can meet technical parameters, namely speed, pressure loss so as to be able to flow clean water. From the results of the analysis, it is found that the need for clean water customers in 2020 is $47.63 \mathrm{lit} / \mathrm{sec}$ with the largest total customer demand in $2030 \mathrm{is} 91.23 \mathrm{lit} / \mathrm{sec}$. This is because the potential of water sources can only serve the needs of the population until 2024.
\end{abstract}

Keyword

Water Distribution System, Epanet 2.2, Evaluation and Strategic Development Plan 2011-2030.

\section{Introduction}

The clean water distribution system in East Timor has started to develop since the Portuguese colonial government in 1515-1974. After Indonesia ruled for 24 years in East Timor clean water infrastructure began to develop well until East Timor became independent. In an effort to utilize clean water sources, the government established a public company named BEE TIMOR-LESTE, E.P (BTL, E.P) based on Decree Law No. 41/2020 for controlling conditions on the ground and developing a clean water distribution network system in East Timor.

The primary objective is to promote greater efficiency and sustainability for the implementation of the Government's strategy in providing water and sanitation services to the public especially in the Post Administrative Dom Aleixo Dili Municipality in accordance with the Strategic Development Plan 2011-2030 and upcoming SDG 6 (Sustainable Development Goal).

Recently the community Post Administrative Dom Aleixo has reached quite a large number with the increase in population every year, the necessities of life that must to be met are also getting bigger, one of the main necessities of life the need for clean water because water is one of the needs of creatures in human life that has a very vital function that must be fulfilled when necessary, because daily human activities are never separated from water. Starting from bathing, washing clothes, cooking or drinking, washing kitchen utensils, washing vehicles, watering plants and which one of the elements human body also consists of clean water. One of the main obstacles faced is the lack of availability of clean water, even the unavailability of clean water services in rural areas and clean water sources that have not been used optimally.

Post Administrative Dom Aleixo is one Post Administrative served by BTL, E.P Dili Municipality with an area of $33.12 \mathrm{~km}^{2}$, total population in 2015 as many 130,095 inhabitants, divided into 7 Sucos that is Suco Bairro Pite, Bebonuk, Comoro, Fatuhada, Kampung Alor, Madohi, Manleuana.

\section{Methodology}

After knowing the research location, then carried out data collection that needs to be done in conducting the study. Data required include: evaluated population data, topographical data and provisioning facilities existing clean water, BTL, E.P Post Administrative Dom Aleixo service data in Dili Municipality on end of 2030. To project the population, we use 3 methods, namely Geometric, Exponential and Arithmetic, after our trial, we choose the most appropriate Geometric method using a population trial for the next 10 years.

In this method used Epanet 2.2 program. The data needed in Epanet 2.2 is a map of the network system, the elevation of each junction, the water discharge, pipe and the pipe roughness value. 
Table 1. Population Data

\begin{tabular}{|c|c|c|c|c|}
\hline \multirow[t]{2}{*}{ No. } & \multirow{2}{*}{\multicolumn{2}{|c|}{ Suco }} & \multicolumn{2}{|c|}{ Total Population } \\
\hline & & & 2010 & 2015 \\
\hline 01. & \multicolumn{2}{|c|}{ Bairo-Píte } & 27875 & 34993 \\
\hline 02. & \multicolumn{2}{|c|}{ Comoro } & 65404 & 76681 \\
\hline 03. & \multicolumn{2}{|c|}{ Fatuhada } & 7178 & 14890 \\
\hline 04. & \multicolumn{2}{|c|}{ Kampung Alor } & 4697 & 3531 \\
\hline 05. & \multicolumn{2}{|c|}{ Madohi } & New Suco & New Suco \\
\hline 06. & Bebonuk & New Suco & New Suco & \\
\hline \multirow[t]{2}{*}{07.} & Manleuana & New Suco & New Suco & \\
\hline & Total & 105154 & 130095 & \\
\hline
\end{tabular}

\subsection{Site Location}

Location analysis was carried out by direct observation to see the existing conditions in the field and data from BTL, E.P Post Administrative Dom Aleixo branch with area is $33.12 \mathrm{~km}^{2}$. It is divided into 7 (seven) Suco nomely Bairo-Píte Suco, Bebonuk Suco, Comoro Suco, Fatuhada Suco, Kampung Alor Suco, Madohi Suco and Manleuana Suco.

In this study, there were only 4 (four) suco such as the Bairo-Píte Suco, Comoro Suco, Fatuhada Suco and Kampung Alor Suco according to the data we got from the agency, namely the Directorate General of Statistics of Timor-Leste and the Post Administration Dom Aleixo. The following is the area and map of the Dom Aleixo Administrative Post as shown in diagram 1 and figure 1.

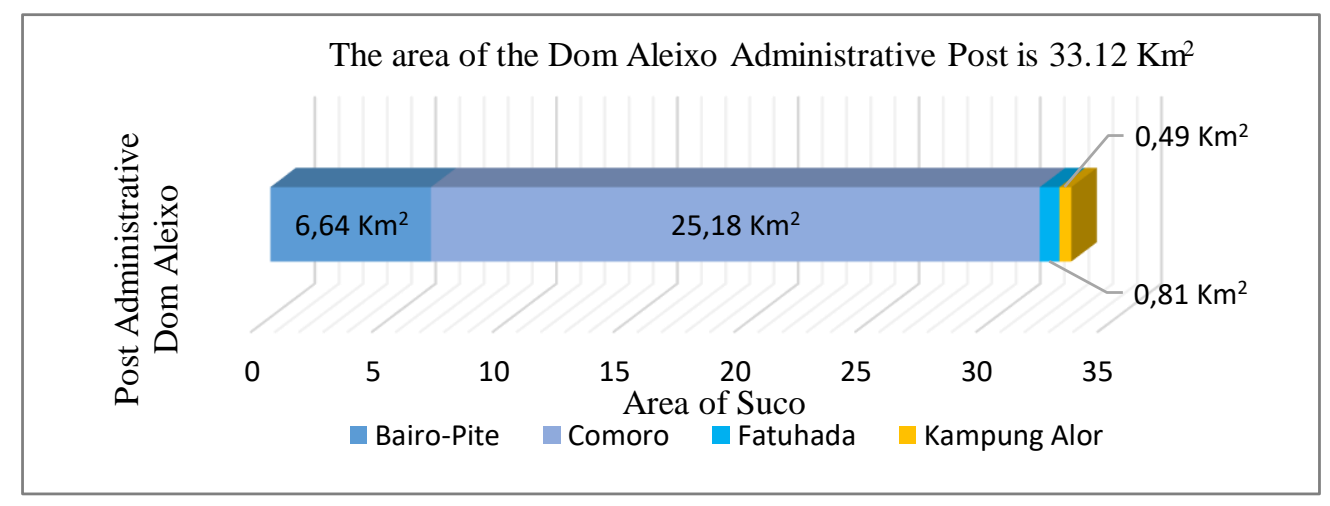

Diagram 1. Area of Post Administrative Dom Aleixo

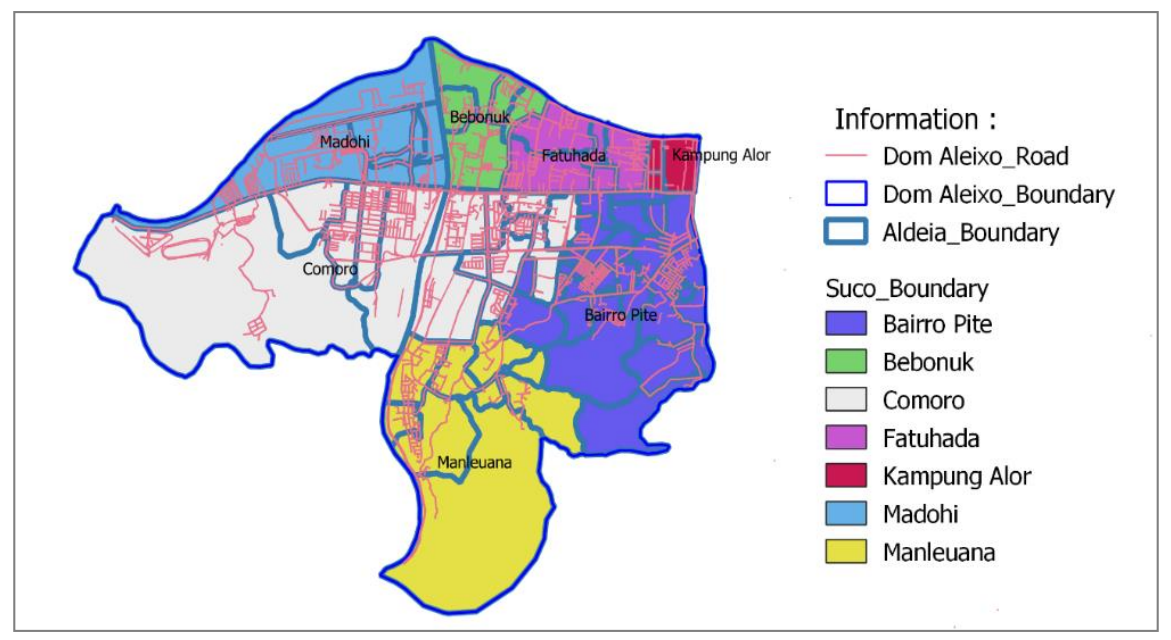

Figure 1. Map of Post Administrative Dom Aleixo

This work is licensed under a Creative Commons Attribution-ShareAlike 4.0 International License. 


\subsection{Analysis Stage}

The stages of case studies in this research are made systematically and regularly based on the steps and concepts of research completion as follows : (Rashid et al., 2019)

1. Start

2. Problem identification

3. Initial orientation

4. Literature study

5. Survey data collection

6. Data analysis

7. Conclusions and suggestions

8. Finish

For more details about the stages of case studies in this research and concepts of research completion as follows:

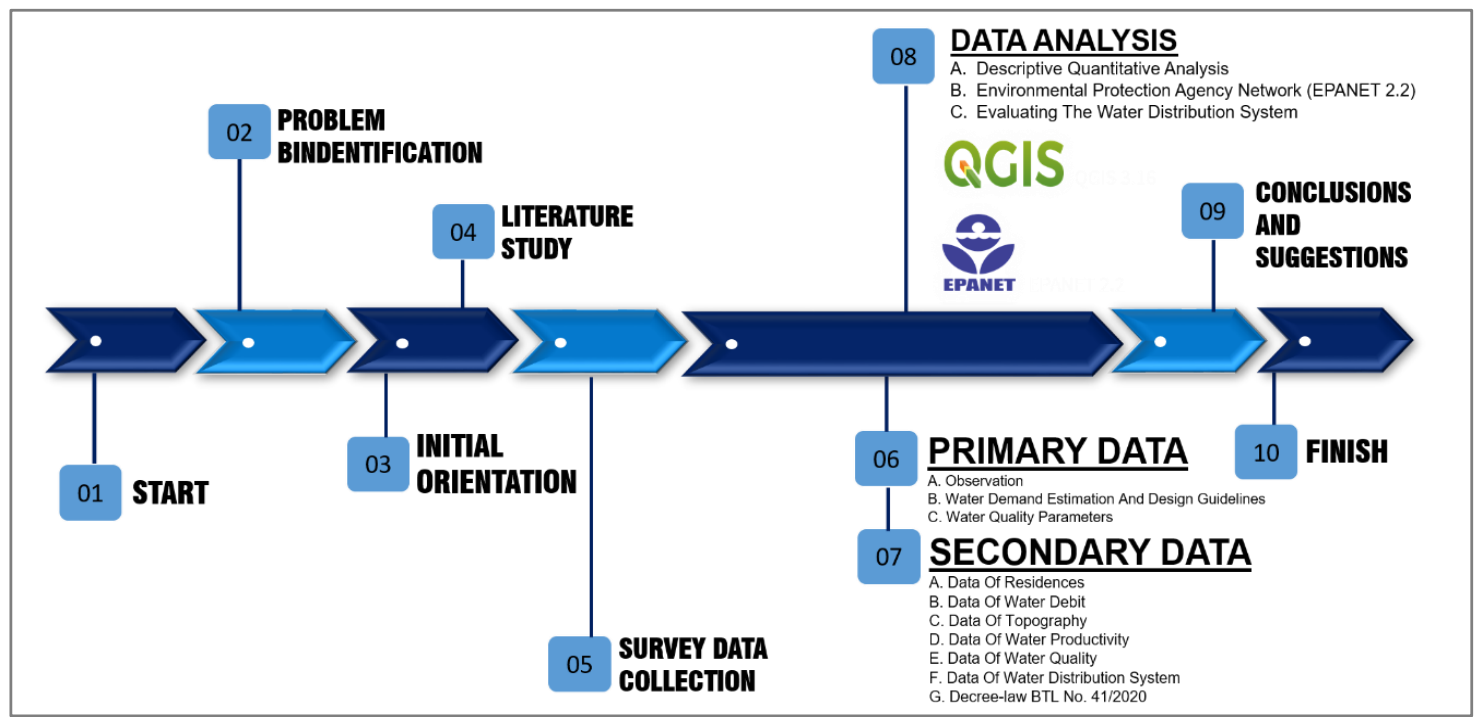

Figure 2. Research Flowchart

\section{Results and Discussion}

\subsection{Projection of Population Growth}

Population growth per Suco in Post Administrative Dom Aleixo according to the results of data analysis by census population 2010 and 2015 how to calculate the population growth rate to determine the rate of increase future users of clean water services. For the results of analysis 2021 shown in table 2.

\begin{tabular}{ccccccc}
\hline No. & Suco & \multicolumn{2}{c}{ Total Population } & Area $(\mathbf{k m})$ & $\begin{array}{c}\text { r } \\
\text { (growth }\end{array}$ & $\begin{array}{c}\text { r (growth rate) } \\
\text { in \% }\end{array}$ \\
& & 2010 & 2015 & & & \\
rate) & & \\
\hline 01. & Bairo-Píte & 27875 & 34993 & $6.64 \mathrm{~km}^{2}$ & 0,047 & $3 \%$ \\
02. & Comoro & 65404 & 76681 & $25.18 \mathrm{~km}^{2}$ & 0,032 & $16 \%$ \\
03. & Fatuhada & 7178 & 14890 & $0.81 \mathrm{~km}^{2}$ & 0,157 & $-6 \%$ \\
04. & Kampung Alor & 4697 & 3531 & $0.49 \mathrm{~km}^{2}$ & $-0,055$ & $18 \%$ \\
\hline
\end{tabular}

Table 2. Population Growth per Suco

\subsection{Population Projection}

In planning the need for clean water for the population in the next 10 years, population data for the next 10 years in needed. The following uses the geometric method to project the population in 2020 to 2030 in the future.

Projection of the population using this geometric method every years, starting from 2020-2030 according of census population 2015. For the results of analysis 2021 shown in table 3. 
Table 3. Population Projection Post Administrative Dom Aleixo

\begin{tabular}{ccccc}
\hline Year & \multicolumn{3}{c}{ Population Projection Using Geometric Method } \\
& Bairo-Píte & Comoro & Fatuhada & Kampung Alor \\
\hline $\mathbf{2 0 2 0}$ & 43929 & 89902 & 30888 & 2654 \\
$\mathbf{2 0 2 1}$ & 45973 & 92809 & 35741 & 2507 \\
$\mathbf{2 0 2 2}$ & 48112 & 95809 & 41356 & 2368 \\
$\mathbf{2 0 2 3}$ & 50351 & 98906 & 47854 & 2237 \\
$\mathbf{2 0 2 4}$ & 52694 & 102103 & 55373 & 2113 \\
$\mathbf{2 0 2 5}$ & 55146 & 105403 & 64073 & 1996 \\
$\mathbf{2 0 2 6}$ & 57712 & 108811 & 74140 & 1885 \\
$\mathbf{2 0 2 7}$ & 60398 & 112328 & 85789 & 1780 \\
$\mathbf{2 0 2 8}$ & 63208 & 115959 & 99269 & 1682 \\
$\mathbf{2 0 2 9}$ & 66150 & 119708 & 114866 & 1588 \\
$\mathbf{2 0 3 0}$ & 69228 & 123577 & 132913 & 1500 \\
\hline
\end{tabular}

\subsection{Projected Clean Water Demand}

The calculation of domestic water is based on the projected population of the year planning, it can be categorized as metropolitan city water needs net 120 liters/person/day. The average number of people per house or per connection is 6 (six) people.

The customers served by BTL, E.P at the Post Administrative Dom Aleixo are currently $67 \%$ of the total 11,917 households usage water 8580240 liter per day, meanwhile 5,809 households have not been served with a percentage of $33 \%$ according to 2015 population census data. For more details about total household's per suco usage water every day as follows:

Table 4. Water Demand Data Post Administrative Dom Aleixo

\begin{tabular}{ccccc}
\hline No. & Suco & $\begin{array}{c}\text { Amount Customer } \\
\text { (households) }\end{array}$ & $\begin{array}{c}\text { Usage Water } \\
\text { (1/day) }\end{array}$ & $\begin{array}{c}\text { Usage } \\
\text { Water (1/sec) }\end{array}$ \\
\hline $\mathbf{0 1}$. & Bairo-Píte & 4115 & 2962800 & 34,319166667 \\
$\mathbf{0 2}$. & Comoro & 4939 & 3556080 & 41,15833333 \\
$\mathbf{0 3}$ & Fatuhada & 1229 & 884880 & 10,2416667 \\
$\mathbf{0 4}$ & Kampung Alor & 1634 & 1176480 & 13,61666667 \\
& Total & 11917 & 8580240 & 99,30833333 \\
\hline
\end{tabular}

\subsection{Calculation of Projected Water Needs}

The following is the calculation of clean water needs in Suco Bairo-Píte, Suco Comoro, Suco Fatuhada and Suco Kampung Alor according to service data from BTL, EP in 2020 and also uses the results of the number of families or households in the census 2015 to target water services clean in the next 10 years.

Table 5. Projection of Clean Water in the Next 10 Years

\begin{tabular}{|c|c|c|c|c|c|c|c|c|}
\hline Year & $\begin{array}{c}\% \text { of } \\
\text { Population } \\
\text { Service } \\
(\%)\end{array}$ & $\begin{array}{c}\text { Water } \\
\text { Needs } \\
\text { (lit/per/d } \\
\text { ay) }\end{array}$ & $\begin{array}{c}\text { Domest } \\
\text { ic } \\
\text { Needs } \\
\text { (lit/day } \\
\text { ) }\end{array}$ & $\begin{array}{c}\text { Non } \\
\text { Domesti } \\
\text { c Needs } \\
\text { (lit/day) }\end{array}$ & $\begin{array}{l}\text { Social } \\
\text { Needs } \\
\text { (lit/day } \\
\text { ) }\end{array}$ & $\begin{array}{c}\text { Total } \\
\text { Requirem } \\
\text { ent } \\
\text { (lit/day) }\end{array}$ & $\begin{array}{c}\text { Total } \\
\text { Maximu } \\
\text { m Daily } \\
\text { Needs } \\
\text { (lit/day) }\end{array}$ & $\begin{array}{c}\text { Total } \\
\text { Demand } \\
\text { at Peak } \\
\text { Hours } \\
\text { (lit/day) }\end{array}$ \\
\hline 2020 & 67 & $\begin{array}{c}2008478 \\
1\end{array}$ & 658781 & $\begin{array}{c}1646952 \\
1\end{array}$ & $\begin{array}{c}16469 \\
521\end{array}$ & 33597822 & $\begin{array}{c}4838086 \\
4\end{array}$ & 70555427 \\
\hline 2021 & 70 & $\begin{array}{c}2124351 \\
8\end{array}$ & 696787 & $\begin{array}{c}1741968 \\
4\end{array}$ & $\begin{array}{c}17419 \\
684\end{array}$ & 35536156 & $\begin{array}{c}5117206 \\
5\end{array}$ & 74625928 \\
\hline 2022 & 74 & $\begin{array}{c}2251742 \\
3\end{array}$ & 738571 & $\begin{array}{c}1846428 \\
7\end{array}$ & $\begin{array}{c}18464 \\
287\end{array}$ & 37667146 & $\begin{array}{c}5424069 \\
0\end{array}$ & 79101006 \\
\hline 2023 & 77 & $\begin{array}{c}2392171 \\
6\end{array}$ & 784632 & $\begin{array}{c}1961580 \\
7\end{array}$ & $\begin{array}{c}19615 \\
807\end{array}$ & 40016247 & $\begin{array}{c}5762339 \\
6\end{array}$ & 84034119 \\
\hline 2024 & 80 & $\begin{array}{c}2547391 \\
3\end{array}$ & 835544 & $\begin{array}{c}2088860 \\
9\end{array}$ & $\begin{array}{c}20888 \\
609\end{array}$ & 42612762 & $\begin{array}{c}6136237 \\
7\end{array}$ & 89486799 \\
\hline 2025 & 84 & $\begin{array}{c}2719418 \\
4\end{array}$ & 891969 & $\begin{array}{c}2229923 \\
1\end{array}$ & $\begin{array}{c}22299 \\
231\end{array}$ & 45490431 & $\begin{array}{c}6550622 \\
1\end{array}$ & 95529905 \\
\hline
\end{tabular}

This work is licensed under a Creative Commons Attribution-ShareAlike 4.0 International License. 
VOLUME 21 | NUMBER 02 | JANUARY 2022 https://ejournal.worldconference.id/index.php/neutron

E-ISSN: 2685-3272 | P-ISSN 1412-0860

\begin{tabular}{ccccccccc}
\hline & & & & & & & \\
\hline 2026 & 87 & 2910576 & 954669 & 2386672 & 23866 & 48688127 & 7011090 & 10224506 \\
& & 7 & & 9 & 729 & & 4 & 8 \\
2027 & 90 & 3123544 & 102452 & 2561306 & 25613 & 52250650 & 7524093 & 10972636 \\
& & 4 & 3 & 4 & 064 & & 6 & 6 \\
2028 & 93 & 3361409 & 110254 & 2756355 & 27563 & 56229649 & 8097069 & 11808226 \\
& & 0 & 2 & 3 & 553 & & 4 & 3 \\
2029 & 97 & 3627731 & 118989 & 2974739 & 29747 & 60684690 & 8738595 & 12743784 \\
& & 4 & 6 & 7 & 397 & & 4 & 9 \\
2030 & 100 & 3926619 & 128793 & 3219828 & 32198 & 65684492 & 9458566 & 13793743 \\
& & 6 & 1 & 0 & 280 & & 8 & 3 \\
\hline
\end{tabular}

\subsection{Water Recourse and Water Usage Fluctuation}

Water resources provided for the Dom Aleixo administrative post are divided into two, namely water from rivers (water above ground) and water from pumps (water below ground). The river originates from two rivers, namely the Tohumeta River with an area of $47.2 \mathrm{~km} 2$, and the Maloa River with an area of $5.74 \mathrm{~km} 2$. The source of water from the pump or water below the ground at the Dom Aleixo administrative post consists of 13 (thirteen) pumping stations namely, Bairo-Píte A, Bairo-Píte B, Markoni, Bebonuk, Comoro A, Comoro B, Comoro B1, Comoro C, Comoro D, Comoro E, Inap Office, Brimob and Manleuana.

According to the results of the calculation of water needs, the calculation of fluctuations in water demand for the Dom Aleixo administrative post service area in 2030 is as follows:

Table 6. Projection of Fluctuations in Water Demand

\begin{tabular}{cccccc}
\hline Year & $\begin{array}{c}\text { Total } \\
\text { population } \\
\text { (person) }\end{array}$ & $\begin{array}{c}\text { Demand } \\
\text { (person) }\end{array}$ & $\begin{array}{c}\text { Water Needs } \\
\text { (liter/person/day) }\end{array}$ & $\begin{array}{c}\text { Water } \\
\text { Production } \\
\text { (liter/day) }\end{array}$ & $\begin{array}{c}\text { Residual Water } \\
\text { And Water Loss } \\
\text { (liter) }\end{array}$ \\
\hline 2020 & 167373 & 27896 & 20084781 & 24747748 & 4662967 \\
2021 & 177029 & 29505 & 21243518 & 24747748 & 3504230 \\
2022 & 187645 & 31274 & 22517423 & 24747748 & 2230325 \\
2023 & 199348 & 33225 & 23921716 & 24747748 & 826032 \\
2024 & 212283 & 35380 & 25473913 & 24747748 & -726165 \\
2025 & 226618 & 37770 & 27194184 & 24747748 & -2446436 \\
2026 & 242548 & 40425 & 29105767 & 24747748 & -4358019 \\
2027 & 260295 & 43383 & 31235444 & 24747748 & -6487696 \\
2028 & 280117 & 46686 & 33614090 & 24747748 & -8866342 \\
2029 & 302311 & 50385 & 36277314 & 24747748 & -11529566 \\
2030 & 327218 & 54536 & 39266196 & 24747748 & -14518448 \\
\hline
\end{tabular}

\subsection{Clean Water Network Hydraulic Analysis with Epanet 2.2 Program}

The clean water distribution network system at the Dom Aleixo administrative post uses a gravity system. This network system is in accordance with topographic conditions that have a high enough elevation difference. This clean water network system uses PVC type pipes with Hazen-Williams $C=140$. Meanwhile, the pipe diameters used vary and the basic planning is carried out as follows:

1. Pipe diameter data and pipe types come from distribution network data via BTL, E.P Dom Aleixo administrative post and also field surveys to obtain maximum power.

2. Elevation data is obtained using the Google Earth program and tracking results using the Global Positioning System (GPS) in the field after that, digitizing the map data using the Quantum GIS (Geographic Information System) program, QGIS.

3. The peak hour factor (Phour) is 1.75 in accordance with the standard peak hour for the Metropolitan City category with peak hours in the morning between 06:00 OTL - 07:00 OTL and in the afternoon at 18:00 OTL - 19:00 OTL.

For more detailed evaluation results, we can see in the Table 7 as follows:

Table 7. Epanet Evaluation Results from the Residual Head

\begin{tabular}{cccc}
\hline No. & Parameters & Amount of Junction & Percentage \\
\hline 01. & Residual Head < 10 Meter & 14 & $17 \%$ \\
02. & Residual Head > 10 Meter & 73 & $83 \%$ \\
& Total & 87 & $100 \%$ \\
\hline
\end{tabular}


Table 8. Epanet Evaluation Results in terms of Flow Speed

\begin{tabular}{cccc}
\hline No. & Parameters & Number of Pipes & Percentage \\
\hline 01. & $0,3 \mathrm{~m} / \mathrm{sec}-2 \mathrm{~m} / \mathrm{sec}$ & 62 & $71 \%$ \\
02. & Head loss $<10 \mathrm{~m} / \mathrm{km}$ & 25 & $29 \%$ \\
& Total & 87 & $100 \%$ \\
\hline \multicolumn{4}{c}{ Table 9. Epanet Evaluation Results Judging from Remaining Press / Head loss } \\
\hline No. & Parameters & Number of Pipes & Percentage \\
\hline 01. & Head loss $>10 \mathrm{~m} / \mathrm{km}$ & 18 & $20 \%$ \\
02. & Residual Head $>10$ Meter & 69 & $80 \%$ \\
\multicolumn{4}{c}{ Total } \\
\hline
\end{tabular}

\section{Conclusion}

Based on the results of data analysis in this research study, the following conclusions can be drawn:

1. The results of the projected population for the Dom Aleixo Administrative Post service area in 2030 based on the geometric method, namely 327,218 people in the sucos of Bairro-Píte, Comoro, Fatuhada and Kampung Alor.

2. The results of the calculation of water needs in 2030 to come are:

a. Suco Bairo-Píte average daily demand is 16675797 liter/day, maximum demand is 23160828704 liter/sec and total demand during peak hours is 33776208333 liter/sec with the percentage of service in 2030 is $22 \%$.

b. Suco Comoro average daily demand is 29767657 liter/day, maximum demand is 41343967593 liter/sec and total demand during peak hours is 60293287037 liter/sec with the percentage of service in 2030 is $25 \%$.

c. Suco Fatuhada the average daily demand is 32016580 liter/day, the maximum demand is 44467472222 liter/sec and the total demand during peak hours is 64848396991 liter/sec with the percentage of service in 2030 is $28 \%$.

d. Suco Kampung Alor the average daily requirement is 361356 liters/day, the maximum demand is 501884259 liters/sec and the total demand at peak hours is 731914352 liters/sec with the percentage of service in 2030 is $25 \%$.

3. From the simulation results of the Epanet 2.2 program for the development of a clean water distribution network system at the Dom Aleixo administrative post, it is known that there are 46 nodes that have residual pressure below the BTL, EP standard in 2020. Repairs are needed for $30 \%$ of pipes due to pipe diameters that are no longer able to drain. Water according to hydraulic criteria standards. Improvement efforts that can be made are by replacing the pipe diameter to reduce water loss by $20 \%$ and can meet technical parameters, namely speed, pressure loss and residual pressure so that clean water can flow to the service area according to hydraulic criteria.

\section{Development Suggestions}

From the research that the author conducted and the problems found, the researchers provide suggestions that are expected to be able to build or be used as input or consideration by the government, especially the clean water public riots in Timor-Leste related to maximizing the management of clean water distribution networks in Timor-Leste, especially in Timor-Leste. Dom Aleixo Administrative Posts are as follows:

1. In the future development of a clean water distribution network system at the Dom Aleixo administrative post, calculations can be made to increase the storage capacity so that it can meet future water needs.

2. New installations to replace old pipes at the Dom Aleixo Administrative Post because through observations from researchers, pipes in the area still use the old pipes and replace the installed water treatment facilities because there are damaged facilities.

3. For the 15 to 20 year development plan should look for new water sources. This is because the potential water source of the Dom Aleixo Administrative Post can only serve the needs of the population until 2024.

4. Controlling the clean water treatment system with proper functioning and testing every day and every month.

5. For students who want to plan a clean water distribution network system, they can use the EPANET program because it has benefits in its use. And need to learn better in the use of the EPANET program.

\section{Acknowledgements}

Praise and gratitude I pray for the presence of God Almighty for His grace so that I can compose and complete the journal entitled "Evaluation of Clean Water Distribution Development in Bee Timor-Leste, E.P Post This work is licensed under a Creative Commons Attribution-ShareAlike 4.0 International License. 
Administrative Dom Aleixo Dili Municipality". As a Human I am aware of limitations, shortcomings and mistakes. However, I have tried my best to do my best. I take this opportunity to express my deepest gratitude to:

1. My parents, my beloved brothers and sisters, as my encouragement, and who have given me a lot of moral and material support and prayers.

2. Local authority in Post Administrative Dom Aleixo, President of Bee Timor-Leste, Empresa Pública and Director General of Statistics Timor-Leste give the time to do my research in the midst of their respective activities during the covid-19 pandemic.

3. Mrs. Dr. Ling. Ir. Sri Sumiyati, S.T., M.Si., IPM and Mr. Ir. M. Arief Budihardjo, S.T., M.Eng.Sc., Ph.D., IPM as Advisors in the completion of this journal.

4. All teaching staff and employees majoring in Environmental Engineering Masters and International Relations Office (IRO) Diponegoro University Semarang who have helped a lot in the lecture process and in the administrative process.

5. Fellow all students of Environmental Engineering at Diponegoro University, Mr. Anor Sihombing's and family and beloved girlfriend Dália Soares Pereira and all those who have prayed for helped and supported both morally and materially in the preparation of this journal.

Finally, the author expresses his deepest gratitude for the completion of the journal with perseverance, high motivation to continue learning and trying, the author has successfully completed the work of this journal. Hopefully, the writer of this journal will be able to make a positive contribution to the world of education.

\section{References}

Emilio Pereira, Elias dos Santos Ferreira, L.Ec., MM, Silvino Lopes \& Helder HM . (2019). Dili em Números, 2019. PDF, Direcção Geral de Estatística Timor-Leste, Estatística Município de Dili, Dili. doi: $7^{\circ}$ Edição 2019

Presidente da República. (2020, September 25). Decreto-Lei N. ${ }^{\circ} 41$ /2020 de 25 de Setembro. Jornal da Repúbca, 1(No. 39 A), 10. Retrieved November 25, 2021

Statistics Timor-Leste, General Directorate of Statistics. (2020). (IS Unit, Ministry of Finance Timor-Leste) Retrieved August 18, 2021, from www.statistics.gov.tl : https://www.statistics.gov.tl/

Timor-Leste Strategic Development Plan 2011-2030. (2011). In Timor-Leste Strategic Development Plan 2011 2030 (p. 77). Palácio do Governo, Edifício 1, R/C, Avenida Presidente Nicolau Lobato, Dili, Timor-Leste, Dili, Timor-Leste. Retrieved June 23, 2021, from https://www.adb.org/sites/default/files/linkeddocuments/cobp-tim-2014-2016-sd-02.pdf

WaterAid Timor-Leste. (2021). Retrieved June 23, 2021, from WaterAid: https://www.wateraid.org/au/

\section{Biography}

Zeferino Soares Lopes is the name of the author of this Journal. The author was born in Maubisse, East Timor on February 25, 1996, and the eldest of five children from Mr. José Casimiro Lopes and Mrs. Madalena da Costa. In 2008 the author graduated from primary school No. 1 Maubisse Villa, in 2011 graduated from Junior High Scholl SMPK Sagrado Coração de Jesus Aituto, Ainaro in 2014 graduated from Senior High School at SMAK São José Operário Balíde Dili, Timor-Leste. In 2016 the author was accepted as a student with the Civil Engineering study program at Narotama University Surabaya, Indonesia though an International Scholarship with a period of four years, graduating in the 2020. After graduated author get more opportunity from Diponegoro Master Scholarship to continue study program in master's degree at Diponegoro University Semarang, Indonesia. In 2022 Praise God will lead the author to get a master's degree in Environmtal Engineering. The author also active in the world of movements and national organizations, International organizations like Toastmasters Club, Rotary Club and etc. Currently the author works at CRIG-COVEC International Company as an Environmental Officer until now. Author Motto "Success Comes From Effort". 